JMI Vol. 42 No. 1, Juni 2020

METAL INDONESIA

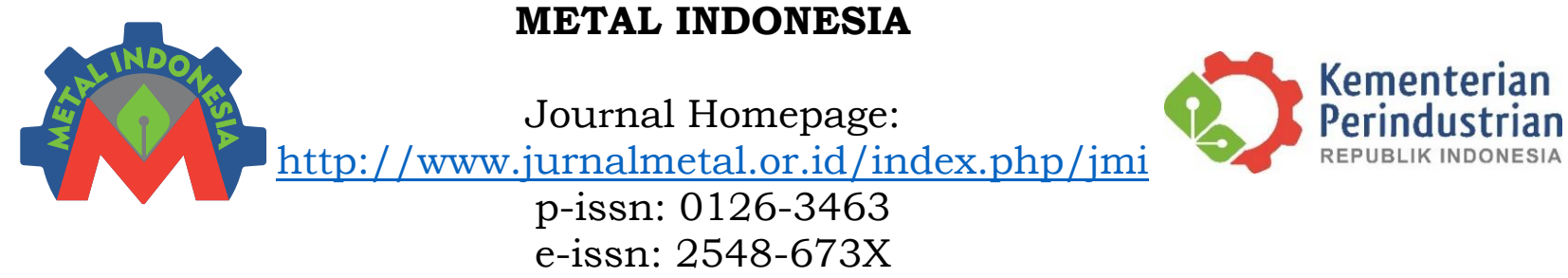

\title{
OPTIMASI PRESIPITASI LOGAM TANAH JARANG DARI CAMPURAN KONSENTRAT LOGAM TANAH JARANG DENGAN METODE "RESPONSE SURFACE METHODOLOGY"
}

\section{OPTIMIZATION OF RARE EARTH PRECIPITATION FROM MIXED RARE EARTH CONCENTRATES WITH RESPONSE SURFACE METHODOLOGY}

\author{
Akbar Yulandra ${ }^{1}$, Iga Trisnawatia ${ }^{1,2}$, I Made Bendiyasa ${ }^{1,3}$, Wahyu Rachmi pusparini ${ }^{2}$, \\ Himawan Tri Bayu Murti Petrus*1,3 \\ ${ }^{1}$ Departemen Teknik Kimia (Sustainable Mineral Processing Research Group), \\ Faculty of Engineering, Universitas Gadjah Mada, Jl. Grafika No. 2 Yogyakarta, 55281 \\ ${ }^{2}$ Pusat Sains dan Teknologi Akselerator, BATAN, Jl. Babarsari Kotak Pos 6101 ykbb Yogyakarta \\ ${ }^{3}$ Unconventional Geo-resources Research Group, Faculty of Engineering, \\ Universitas Gadjah Mada, Jl. Grafika No. 2, Yogyakarta 55281 \\ Email: *bayupetrus@ugm.ac.id
}

\begin{abstract}
Abstrak
Dua sumber LTJ berasal dari mineral seperti monasit dan senotim. Ketersediaan LTJ di kerak bumi relatif sedikit, tersebar dan jarang terjadi dalam bentuk bijih. Dalam penelitian ini bahan baku yang digunakan adalah campuran konsentrat LTJ yang berasal dari PT. Monokem Surya. Tujuan dari penelitian ini adalah untuk mengetahui pengaruh konsentrasi $\mathrm{H}_{2} \mathrm{C}_{2} \mathrm{O}_{4}$, kecepatan pengadukan dan suhu terhadap kemurnian dan pemungutan LTJ dari campuran konsentrat LTJ. Percobaan dilakukan dalam lima langkah: (1) Fusi alkali, proses dilakukan selama 3 jam pada suhu $450^{\circ} \mathrm{C}$, dengan rasio padatan $\mathrm{NaOH}$ terhadap campuran konsentrat LTJ sebesar 1:1, untuk memutuskan ikatan fosfat; (2) ) Pelindian fosfat dalam produk fusi alkali menggunakan aquadest pada suhu $80^{\circ} \mathrm{C}$; (3) Residu pelindian aquadest dilakukan proses perlindian menggunakan $6 \mathrm{M} \mathrm{HCl}$ selama 2 jam untuk melarutkan LTJ pada $90^{\circ} \mathrm{C}$; (4) Menghilangkan kotoran seperti uranium dan thorium dengan mengendapkannya menggunakan $\mathrm{NH}_{4} \mathrm{OH}$ pada $\mathrm{pH}$ 1; (5) Presipitasi LTJ dari filtrat yang dihasilkan dari butir (4) menggunakan $\mathrm{H}_{2} \mathrm{C}_{2} \mathrm{O}_{4}$. Didapatkan hasil LTJ dengan kemurnian $96 \%$ dan pemungutan sebesar $95 \%$ pada konsentrasi $\mathrm{H}_{2} \mathrm{C}_{2} \mathrm{O}_{4} 8,11 \%$, kecepatan putar pengaduk $500 \mathrm{rpm}$, dan suhu $70^{\circ} \mathrm{C}$.
\end{abstract}

Kata kunci: Fusi alkali, Pelindian, presipitasi , Logam Tanah Jarang, $\mathrm{H}_{2} \mathrm{C}_{2} \mathrm{O}_{4}$

\begin{abstract}
Two sources of REEs are from mineral monazite and xenotime. The availability of REEs is relatively abundant in the earth's crust, typically dispersed, and rarely occur in ores. In this study as raw material was a mixed rare earth concentrate from Monokem Surya Ltd. The purposes of this research were to determine the effect of concentration $\mathrm{H}_{2} \mathrm{C}_{2} \mathrm{O}_{4}$, stirring speed, and temperature regarding to purity and recovery REEs from the mixed rare earth concentrate. The experiments were conducted in five steps:(1) Alkaline fusion, the process was performed about 3 hours at $450^{\circ} \mathrm{C}$, with ratio of $\mathrm{NaOH}$ solid to the mixed rare earth concentrate sand was 1:1, in order to break phosphate bonds;(2) Leaching of phosphate in
\end{abstract}


alkaline fusion product using aquadest at $80^{\circ} \mathrm{C}$; (3) Aquadest leaching residue was leached using $6 \mathrm{M} \mathrm{HCl}$ for 2 hours to dissolve REEs at $90{ }^{\circ} \mathrm{C}$; (4) Removal of impurities such as uranium and thorium by precipitating them using $\mathrm{NH}_{4} \mathrm{OH}$ at $\mathrm{pH}$ 1; (5) Precipitation of REEs from filtrate produced from point (4) using $\mathrm{H}_{2} \mathrm{C}_{2} \mathrm{O}_{4}$. The results of $\mathrm{REES}$ with $96 \%$ purity and $95 \%$ recovery was obtained at concentration $\mathrm{H}_{2} \mathrm{C}_{2} \mathrm{O}_{4} 8,11 \%$, stirring speed $500 \mathrm{rpm}$, and temperature $70^{\circ} \mathrm{C}$.

Keywords: Alkali fusion, leaching, precipitation, rare earth elements, $\mathrm{H}_{2} \mathrm{C}_{2} \mathrm{O}_{4}$

\section{PENDAHULUAN}

Logam tanah jarang (LTJ) merupakan elemen yang sangat penting dalam industri seperti pembuatan katalis dan super konduktor. Sejalan dengan perkembangan teknologi, maka LTJ semakin dibutuhkan misalnya: (1) Yitrium (Y), yang digunakan pada bahan semikonduktor, pembuatan keramik maju dan layar televisi berwarna; (2) Cerium (Ce) yang digunakan untuk katalis pada industri perminyakan; (3) Lantanum (La) digunakan untuk katalis dan superkonduktor; (4) Neodimium (Nd) dan Dysprosium (Dy) digunakan untuk pembuatan komputer dan Magnetic Resonance Imaging; (5) Thorium (Th) dapat digunakan sebagai bahan bakar pembangkit listrik tenaga nuklir (Virdhian dan Afrilinda, 2018; Harjanto dkk., 2013; Hoshino dkk., 2016). Karena berbagai aplikasi LTJ yang luas, faktor politik, fluktuasi harga, ketersediaannya yang sedikit dan permintaan pasar yang tinggi maka pengolahan LTJ menjadi sangat prospektif (Binnemans dkk., 2013).

Kandungan LTJ dalam kerak bumi relatif sedikit dan bersifat menyebar, tetapi jarang sekali dalam bentuk konsentrat. Secara umum LTJ memiliki tivalen kation pada karbonat, oksida, fosfat dan silikat. Mineral LTJ juga dapat membentuk mineral campuran konsentrat LTJ, seperti mineral paragenetik dari bastnasit $\left((\mathrm{Ce}, \mathrm{La})\left(\mathrm{CO}_{3}\right) \mathrm{F}\right)$, monasit $\left((\mathrm{Ce}, \mathrm{La})\left(\mathrm{PO}_{4}\right)\right.$, senotim $\left(\mathrm{YPO}_{4}\right)$. Mineral bastnasit, monasit dan senotim merupakan sumber daya alam utama dalam produksi LTJ di dunia (Prameswara dkk., 2020; Krishnamurthy dan Gupta, 2015; Xie dkk., 2014; Jordens dkk., 2013).

Menurut Krishnamurthy dan Gupta (2015) LTJ sulit diekstraksi karena LTJ memiliki sifat kimia yang hampir sama satu sama lainnya. Proses pengolahan LTJ secara umum terbagi menjadi 3 langkah: (1) Dekomposisi konsentrat mineral senyawa asam atau basa; (2) Proses leaching LTJ dengan menggunakan senyawa asam baik organik maupun anorganik; (3) Proses pemisahan dan pemurnian LTJ dengan metode misalnya presipitasi bertingkat dan ekstraksi.

Galvin dan Safarzadeh (2018) melakukan pengolahan konsentrat LTJ dari monasit melalui 3 tahapan proses dekomposisi campuran LTJ melalui proses roasting dengan $\mathrm{KOH}$ padat suhu $150-250^{\circ} \mathrm{C}$ selama $1-4$ jam; (2) Proses leaching menggunakan $\mathrm{HNO}_{3} 30 \%$ (v/v) pada suhu $70^{\circ} \mathrm{C}$ selama 30 menit; (3) presipitasi LTJ dengan menggunakan asam oksalat $6,2 \% \mathrm{~b} / \mathrm{v}$ diperoleh recovery LTJ sebanyak 90\%. Silva dkk. (2019) melakukan presipitasi LTJ dari liquor sulfuric yang mengandung pengotor terlarut dengan menggunakan asam oksalat. Konsentrasi asam oksalat yang digunakan $5 \% \mathrm{~b} / \mathrm{v}$ dan diperoleh recovery LTJ 96\%. Pada percobaan ini raw material yang digunakan merupakan campuran konsentrat LTJ dari pulau Bangka.

Baru-baru ini banyak metode desain eksperimental statistik digunakan untuk optimasi parameter proses. Optimasi system multivariable dalam teknik konvensional mengikuti satu faktor pada satu waktu. Banyak percobaan diperlukan untuk teknik konvensional dan metode seperti ini tidak mewakili efek gabungan (Bahera dkk., 2018). Tujuan utama dari teknik desain eksperimental adalah untuk memahami interaksi antar parameter, yang dapat membantu dalam optimasi parameter eksperimental dan menyediakan model statistik.

Dalam penelitian-penelitian yang berkaitan dengan optimasi proses dewasa ini telah dikembangkan penggunaan suatu metode yang disebut response surface methodology (RSM). Metode ini merupakan suatu kumpulan teknik penyelesaian masalah dengan menggunakan matematika dan statistik dalam bentuk model matematika dan menganalisis masalah tersebut sehingga respons tersebut berada pada titik optimumnya. RSM banyak digunakan untuk menentukan pengaruh tiap faktor dan interaksi antar faktor serta membuat proses optimasi menjadi lebih efektif (Myers dkk., 2016) 
Tujuan penelitian ini adalah untuk mendapatkan nilai optimum kemurnian dari campuran konsentrat LTJ, dengan mempelajari pengaruh suhu, konsentrasi asam oksalat dan kecepatan putar pengadukan. Parameter proses dioptimalkan dengan menggunakan metode RSM.

\section{METODE PENELITIAN Bahan}

Campuran konsentrat LTJ didapatkan dari PT Monokem Surya, NaOH padat teknis yang diproduksi oleh PT Asahimas Chemical, $\mathrm{HCl}$ yang diproduksi oleh Merck dengan kadar 37\%, $\mathrm{NH}_{4} \mathrm{OH}$ yang diproduksi oleh Merck dengan kadar $25 \%$, asam oksalat $\left(\mathrm{H}_{2} \mathrm{C}_{2} \mathrm{O}_{4}\right)$ yang diproduksi oleh Merck dengan kadar 99,5\%, Air yang digunakan adalah air destilasi.

\section{Proses Fusi Alkali}

Proses fusi alkali diawali dengan mencampurkan $\mathrm{NaOH}$ padat dan campuran LTJ konsentrat ukuran -120 mesh dengan perbandingan berat 1:1 dalam cawan porselen. Proses fusi alkali dilakukan didalam furnace dengan suhu dijaga tetap $450^{\circ} \mathrm{C}$ selama 3 jam dengan tujuan untuk memecah ikatan fosfat.

\section{Proses Leaching Dengan Aquadest}

Hasil proses fusi alkali dilanjutkan dengan proses pelindian dengan aquadest suhu $80^{\circ} \mathrm{C}$ selama 1 jam dalam gelas beker. Tujuannya adalah untuk melarutkan fosfat dari proses fusi alkali. Selanjutnya dilakukan penyaringan untuk memisahkan residu dan filtrat. Hasil residu kemudian dikeringkan dalam oven suhu $110^{\circ} \mathrm{C}$ sampai didapatkan berat konstan. Residu kemudian dianalis dengan Spektroskopi (X-ray fluorescence) XRF (Epsilon 4) di Pusat Sains dan Teknologi Akselerator (PSTA-BATAN) untuk menganalisis kandungan LTJ.

\section{Proses Leaching dengan $\mathrm{HCl}$}

Residu dari proses leaching dengan aquadest selanjutnya dilakukan proses pelindian $\mathrm{HCl} 6 \mathrm{M}$ dengan perbandingan berat residu dan volume $\mathrm{HCl}(\mathrm{S} / \mathrm{L}) 1: 10$ pada suhu $90^{\circ} \mathrm{C}$ selama 2 jam dalam labu leher tiga yang dilengkapi pendingin balik. Tujuan proses perlindian dengan $\mathrm{HCl}$ adalah untuk melarutkan LTJ. Selanjutnya dilakukan penyaringan untuk memisahkan filtrat dan residu. Residu yang telah terpisah dicuci dengan aquadest hingga filtrat cucian mendekati pH 7 lalu dikeringkan di dalam oven pada suhu $110^{\circ} \mathrm{C}$ hingga mendapat berat konstan. Residu yang telah kering kemudian dianalis dengan Spektroskopi ( $X$-ray fluorescence) XRF (Epsilon 4) di PSTA-BATAN untuk menganalisis kandungan LTJ.

\section{Penghilangan Pengotor (Uranium dan Thorium)}

Filtrat hasil leaching $\mathrm{HCl}$ dikenakan proses presipitasi dengan menambahkan larutan $\mathrm{NH}_{4} \mathrm{OH}$ sampai $\mathrm{pH} 1$ dalam gelas beker. Selanjutnya disaring untuk memisahkan filtrat dan presipitat. Presipitat kemudian dicuci dengan aquadest hingga filtrat cucian mendekati $\mathrm{pH} 7$ lalu dikeringkan di dalam oven pada suhu $110^{\circ} \mathrm{C}$ hingga mendapat berat konstan. Presipitat yang telah kering kemudian dianalis dengan Spektroskopi (X-ray fluorescence) XRF (Epsilon 4) di PSTA-BATAN untuk menganalisis kandungan uranium dan thorium.

\section{Presipitasi LTJ dengan $\mathrm{H}_{2} \mathrm{C}_{2} \mathrm{O}_{4}$}

Filtrat dari proses penghilangan pengotor (uranium dan thorium) kemudian dilakukan presipitasi LTJ di dalam gelas beker. Proses diawali dengan menambahkan $\mathrm{H}_{2} \mathrm{C}_{2} \mathrm{O}_{4} 9 \%$ (b/v) pada suhu $30^{\circ} \mathrm{C}$ sambil diaduk kecepatan putar pengaduk $250 \mathrm{rpm}$ selama 30 menit. Setelah 30 menit lalu didiamkan supaya terjadi proses pengendapan kemudian dilakukan penyaringan untuk memisahkan hasil presipitat dengan filtrat. Hasil presipitat kemudian dicuci dengan aquadest hingga filtrat cucian mendekati $\mathrm{pH} 7$ lalu dikeringkan di dalam oven pada suhu $110^{\circ} \mathrm{C}$ hingga mendapat berat konstan. Hasil presipitat dianalis dengan spektroskopi ( $X$-ray fluorescence) XRF (Epsilon 4) di PSTA-BATAN untuk menganalisis kandungan LTJ , spektroskopi $(X$ ray diffraction) XRD (Aeris Research DY 844) di PSTA-BATAN untuk menganalisis kristal LTJ dan spektroskopi (Fourier-transform infrared spectroscopy) FTIR (Bruker, ALPHA II) di PSTA-BATAN untuk menganalisi gugus fungsi LTJ. Proses presipitasi LTJ dengan $\mathrm{H}_{2} \mathrm{C}_{2} \mathrm{O}_{4}$ dengan cara yang sama seperti diuraikan sebelumnya dipelajari pada suhu $\left(30,50,70^{\circ} \mathrm{C}\right)$, kecepatan putar pengaduk $(250,350,500 \mathrm{rpm})$ dan konsentrasi $\mathrm{H}_{2} \mathrm{C}_{2} \mathrm{O}_{4}(1,5$ dan $9 \%)(\mathrm{b} / \mathrm{v})$. 


\section{Optimasi dengan Metode Response Surface Methodology}

Response Surface Methodology (RSM) adalah sekumpulan metode-metode matematika dan statistika yang digunakan dalam pemodelan dan analisis, yang bertujuan untuk melihat pengaruh beberapa variabel kuantitatif terhadap suatu variabel respon dan untuk mengoptimalkan variabel respon tersebut. Tri dkk., (2018) menggunakan model matematika-kuadratik dan analisis varians (ANOVA) untuk pengujian data. Persamaan yang digunakan adalah polynomial orde 2 ditunjukan pada Persamaan. (1)

$$
\begin{aligned}
& y=\beta+\sum_{i=1}^{k} \beta_{i} x_{i}+\sum_{i=1}^{k} \beta_{i i} x_{i}^{2} \\
& +\sum_{i>j}^{k} \beta_{i j} x_{i} x_{j}
\end{aligned}
$$

Dengan $x_{i}$ dan $x_{j}$ mewakili nilai kode dari faktor input yang menentukan respons $(y)$. Selain itu, $\beta, \beta_{i}, \beta_{i i}$ dan $\beta_{i j}$ mewakili koefisien dari persamaan regresi. Pada percobaan ini jumlah faktor adalah $3(k=3)$ sehingga Persamaan (1) menjadi Persamaan (2).

$$
\begin{aligned}
& y=\beta+\beta_{1} x_{1}+\beta_{2} x_{2} \\
& +\beta_{3} x_{3}+\beta_{12} x_{1} x_{2}+\beta_{13} x_{1} x_{3} \\
& +\beta_{23} x_{2} x_{3}+\beta_{11} x_{1}^{2} \\
& +\beta_{22} x_{2}^{2}+\beta_{33} x_{3}^{2}
\end{aligned}
$$

Pada percoba ini digunakan rancangan adalah Box-Behnken Design (BBD). BBD membutuhkan setidaknya tiga level untuk setiap faktor dalam percobaannya (Honary dkk., 2014). Jumlah rancangan percobaan untuk BBD ditentukan dengan Persamaan (3).

$$
N=2 k(k-1)+C_{o}
$$

Dengan $N$ adalah jumlah percobaan yang dilakukan, $k$ adalah jumlah faktor dan $\mathrm{C}_{\mathrm{o}}$ adalah jumlah titik tengah. Pada penelitian ini memiliki tiga variabel bebas (faktor) yaitu konsentrasi $\mathrm{H}_{2} \mathrm{C}_{2} \mathrm{O}_{4}$, kecepatan putar pengaduk dan suhu. Berdasarkan tiga faktor tersebut, maka rancangan percobaan disajikan pada Tabel 1 Dan Tabel 2. Hasil percobaan dioptimasi dengan bantuan software Minitab 18.
Tabel 1. Faktor dan kode level perlakukan pada rancangan percobaan

\begin{tabular}{lcccc}
\hline Faktor & Simbol & \multicolumn{3}{c}{ Kode level } \\
\cline { 3 - 5 } & & -1 & 0 & 1 \\
\hline Suhu $\left({ }^{\circ} \mathrm{C}\right)$ & $x_{1}$ & 30 & 50 & 70 \\
$\begin{array}{l}\text { Kecepatan putar } \\
\text { pengaduk (rpm) }\end{array}$ & $x_{2}$ & 250 & 350 & 500 \\
$\begin{array}{l}\text { Konsentrasi } \\
\mathrm{H}_{2} \mathrm{C}_{2} \mathrm{O}_{4} \%(\mathrm{~b} / \mathrm{v})\end{array}$ & $x_{3}$ & 1 & 5 & 9 \\
\hline
\end{tabular}

Tabel 2. Rancangan percobaan dan respon kemurnian LTJ

\begin{tabular}{ccccc}
\hline & \multicolumn{2}{c}{ Faktor $(x)$} & Respon (y) \\
\cline { 2 - 5 } Percobaan & & & & $\begin{array}{c}\% \\
\text { kemurnian } \\
\text { LTJ }\end{array}$ \\
\hline 1 & $x_{1}$ & $x_{2}$ & $x_{3}$ & 93 \\
2 & -1 & -1 & 0 & 92 \\
3 & 1 & -1 & 0 & 92 \\
4 & -1 & 1 & 0 & 92 \\
5 & 1 & 1 & 0 & 83 \\
6 & -1 & 0 & -1 & 82 \\
7 & 1 & 0 & -1 & 88 \\
8 & -1 & 0 & 1 & 95 \\
9 & 1 & 0 & 1 & 81 \\
10 & 0 & -1 & -1 & 79 \\
11 & 0 & 1 & -1 & 90 \\
12 & 0 & -1 & 1 & 95 \\
13 & 0 & 1 & 1 & 93 \\
14 & 0 & 0 & 0 & 93 \\
15 & 0 & 0 & 0 & 93 \\
\hline
\end{tabular}

\section{HASIL DAN PEMBAHASAN Analisys of Variance (ANOVA)}

Hasil estimasi koefisien persamaan model dari output Minitab 18 ditunjukan pada Tabel 3, menunjukan nilai $\mathrm{P}>$ dari $\alpha(5 \%)$ pada $x_{1}, x_{2}$, $x_{1}^{2}, x_{2}^{2}$ dan $x_{1} \cdot x_{2}$ yang artinya faktor tersebut tidak signifikan secara statistik. Model yang diperoleh dari percobaan ini disajikan dalam Persamaan (4). 


$$
\begin{aligned}
& y=93,120-0,561 x_{1}-0,288 x_{2}+ \\
& 5,709 x_{3}-0,060 x_{1} \cdot x_{2}+1,882 x_{1} \cdot x_{3} \\
& +2,038 x_{2} \cdot x_{3}+0,048 x_{1}^{2} \\
& -0,736 x_{2}^{2}-6,250 x_{3}^{2}
\end{aligned}
$$

Tabel 3. Estimasi koefisien persamaan model dari Minitab 18

\begin{tabular}{ccc}
\hline $\begin{array}{c}\text { Estimasi koefisien } \\
\text { kuadrat }\end{array}$ & Koefisien & Nilai P \\
\hline Konstanta & 93.120 & 0.000 \\
$x_{1}$ & 0.561 & 0.283 \\
$x_{2}$ & 0.288 & 0.560 \\
$x_{3}$ & 5.709 & 0.000 \\
$x_{1}^{2}$ & 0.048 & 0.947 \\
$x_{2}^{2}$ & -0.736 & 0.350 \\
$x_{3}^{2}$ & -6.250 & 0.000 \\
$x_{1} x_{2}$ & 0.060 & 0.929 \\
$x_{1} x_{3}$ & 1.882 & 0.034 \\
$x_{2} x_{3}$ & 2.038 & 0.025 \\
\hline $\mathrm{R}^{2}=0,98 ; \mathrm{R}^{2}$ (adj)=0,94; $\mathrm{R}^{2}($ pred $)=0,68 ;$ \\
$\mathrm{P}<0,05(5 \%)$ berpengaruh secara signifikan
\end{tabular}

Hasil ANOVA yang ditunjukan Tabel 4 dapat disimpulkan bahwa model orde kedua untuk kasus ini adalah model yang tepat. Hal ini dilihat dari nilai nilai $\mathrm{P}$ untuk model lebih besar dari $\alpha=5 \%$ sedangkan untuk model orde kedua nilai $\mathrm{P}$ kurang dari $\alpha$. Untuk memeriksa signifikansi model orde kedua, dapat dilihat nilai $\mathrm{P}$ dari model pada Tabel 4. Nilai $\mathrm{P}=0,001$ lebih kecil dari derajat signifikansi $\alpha=5 \%$, hal ini berarti variabel-variabel independen $x_{i}$ memberikan sumbangan yang berarti dalam model.

Perhitungan untuk optimasi ditampilkan pada Gambar 1 dan didapatkan nilai optimal kemurnian LTJ pada nilai 97,0490. Penentuan daerah optimasi dapat digunakan grafik secara Contour dan Surface. Respon dari hasil penelitian dapat dilihat pada Gambar 2 terlihat bahwa kontur yang dihasilkan terdiri dari berbagai variasi warna. Masing-masing warna menunjukkan kisaran besarnya respon yang dihasilkan. Kondisi maksimal untuk Gambar 2 berada di warna hijau

tua dengan kemurnian LTJ sebesar 97\% dengan nilai recovery $95 \%$ pada suhu $70^{\circ} \mathrm{C}$ dan kecepatan putar pengaduk $500 \mathrm{rpm}$. Silva dkk. (2019) juga melakukan percobaan presipitasi LTJ dengan $\mathrm{H}_{2} \mathrm{C}_{2} \mathrm{O}_{4}$ dengan kemurnian $99,2 \%$ dan recovery sebanyak $96 \%$. Dengan demikian hasil penelitian ini memberikan hasil belum lebih baik dari percobaan Silva dkk. (2019). Dari kisaran warna inilah yang akan memberikan garis besar petunjuk letak titik optimum variabel. Penentuan kondisi optimum dibuktikan dengan bentuk kurva tiga

\begin{tabular}{|c|c|c|c|c|}
\hline Source & $\begin{array}{c}\text { Degree } \\
\text { of } \\
\text { Freedom }\end{array}$ & $\begin{array}{c}\text { Sum } \\
\text { Square }\end{array}$ & $\begin{array}{l}\text { Mean } \\
\text { of } \\
\text { Square }\end{array}$ & Nilai $\mathrm{P}$ \\
\hline Model & 9 & 422.108 & 46.901 & 0.001 \\
\hline Linier & 3 & 258.816 & 86.272 & 0.000 \\
\hline$x_{1}$ & 1 & 2.466 & 2.466 & 0.283 \\
\hline$x_{2}$ & 1 & 0.662 & 0.662 & 0.560 \\
\hline$x_{3}$ & 1 & 255.687 & $\begin{array}{c}255.68 \\
7\end{array}$ & 0.000 \\
\hline Square & 3 & 145.531 & 48.510 & 0.001 \\
\hline$x_{1}^{2}$ & 1 & 0.008 & 0.008 & 0.947 \\
\hline$x_{2}^{2}$ & 1 & 1.809 & 1.809 & 0.350 \\
\hline$x_{3}^{2}$ & 1 & 144.239 & $\begin{array}{c}144.23 \\
9\end{array}$ & 0.000 \\
\hline $\begin{array}{c}\text { 2-Way } \\
\text { Interac } \\
\text { tion }\end{array}$ & 3 & 31.134 & 10.378 & 0.040 \\
\hline$x_{1} x_{2}$ & 1 & 0.015 & 0.015 & 0.929 \\
\hline$x_{1} x_{3}$ & 1 & 14.169 & 14.169 & 0.034 \\
\hline$x_{2} x_{3}$ & 1 & 16.950 & 16.950 & 0.025 \\
\hline Error & 5 & 8.517 & 1.703 & \\
\hline $\begin{array}{l}\text { Lack- } \\
\text { of-Fit }\end{array}$ & 3 & 8.517 & 2.839 & $*$ \\
\hline $\begin{array}{l}\text { Pure } \\
\text { Error }\end{array}$ & 2 & 0.000 & 0.000 & \\
\hline Total & 14 & 430.625 & & \\
\hline
\end{tabular}
dimensi yang membentuk puncak seperti Gambar 3.

Tabel 4. Analysis of Variance dari Minitab 18 


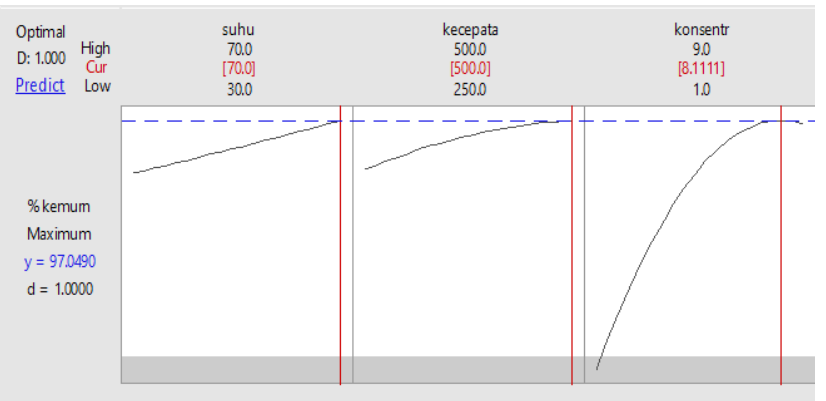

Gambar 1. Grafik optimasi Suhu, kecepatan putar pengadukan, dan konsentrasi $\mathrm{H}_{2} \mathrm{C}_{2} \mathrm{O}_{4}$ untuk presipitasi LTJ

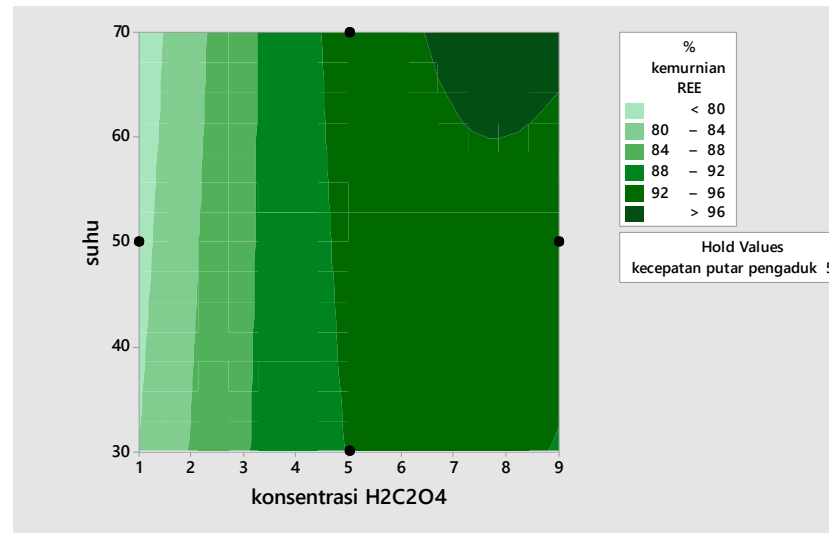

Gambar 2. Response Contour Plot menunjukkan pengaruh perbedaan konsentrasi $\mathrm{H}_{2} \mathrm{C}_{2} \mathrm{O}_{4}$ dan suhu presipitasi terhadap kemurnian LTJ

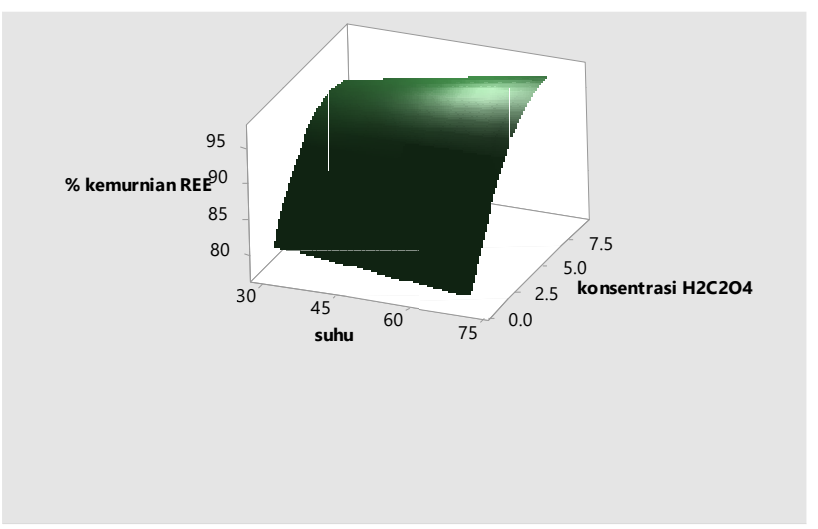

Gambar 3. Response Surface terhadap kemurnian LTJ

\section{Karakteriasi hasil presipitat LTJ}

Karakteriasi hasil presipitasi LTJ dilakukan dengan bantuan spektroskopi FTIR dan XRD. Hasil analisis FTIR presipitasi LTJ adan XRD dilihat pada Gambar 4 dan Gambar 5. Gambar 4 menunjukkan puncak spektrum panjang gelombang 3393,$14 ; 3382,41 ; 3368,13 ; 3350,14$;
$3335,89 . \mathrm{cm}^{-1}$ yang menandakan adanya ikatan gugus $(\mathrm{O}-\mathrm{H})$; 1633,64; 1625,03; menandakan adanya ikatan gugus fungsi $(\mathrm{C}=\mathrm{O})$ (Bellamy dan Pace, 1963).

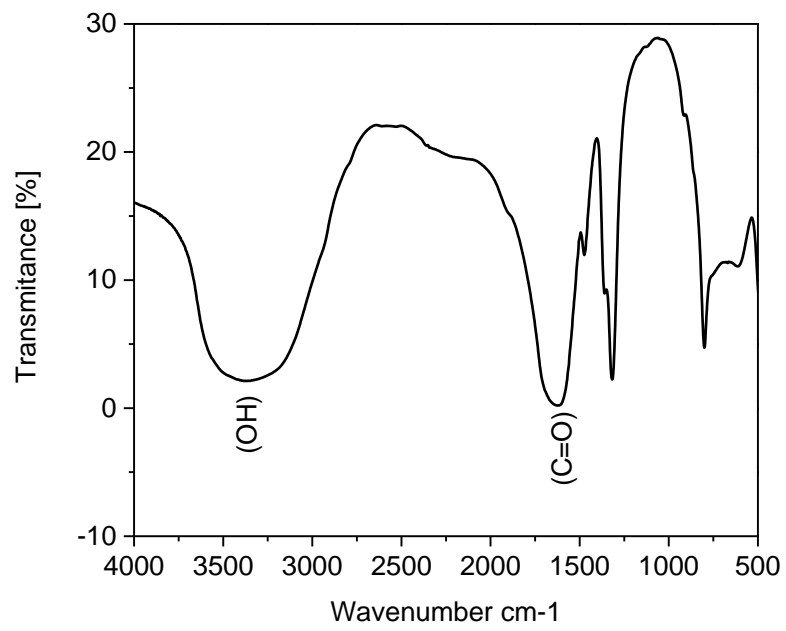

Gambar 4. Karakterisasi FTIR Presipitat LTJ pada konsentrasi 9\%, kecepatan putar pengadukan $500 \mathrm{rpm}$, suhu $70^{\circ} \mathrm{C}$

Gambar 5 menunjukan pola difraksi dari presipitat oksalat posisi 2 theta tertinggi pada $9,97^{\circ}, 15,64^{\circ}$ dan $21,31^{\circ}$ dengan fase kristal $\mathrm{LTJ}_{2}\left(\mathrm{C}_{2} \mathrm{O}_{4}\right)_{3}$. Hasil penelitian ini mendekati hasil penelitian yang diperoleh oleh Liu dkk. (2020), Gambar 6 menunjukan hasil penelitian Liu dkk. (2020) dan terlihat puncak 2 theta tertinggi pada $10^{\circ}, 15^{\circ}$ dan $22^{\circ}$.

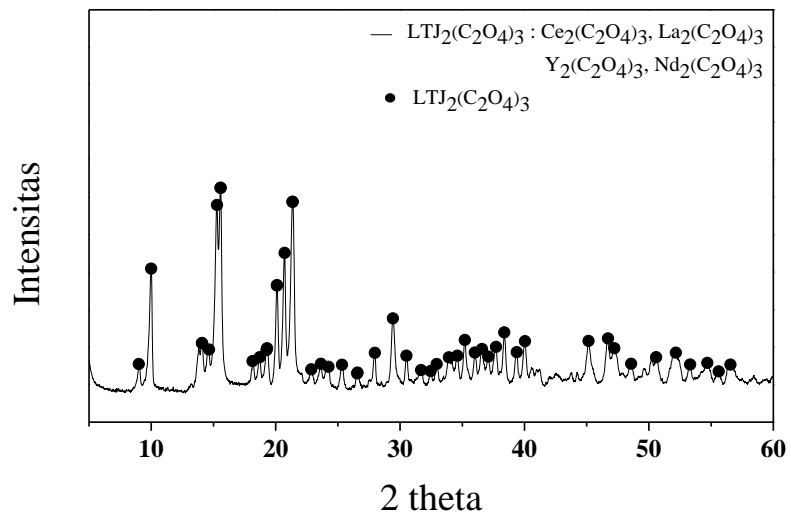

Gambar 5. Karakterisasi XRD hasil percobaan presipitasi LTJ, konsentrasi $\mathrm{H}_{2} \mathrm{C}_{2} \mathrm{O}_{4} 9 \%$, kecepatan putar pengaduk $500 \mathrm{rpm}$, suhu $70^{\circ} \mathrm{C}$

\section{KESIMPULAN DAN SARAN}

Proses presipitasi LTJ terutama dipengaruhi oleh konsentrasi $\mathrm{H}_{2} \mathrm{C}_{2} \mathrm{O}_{4}$ dan suhu. 
Kondisi optimum proses presipitasi: konsentrasi $\mathrm{H}_{2} \mathrm{C}_{2} \mathrm{O}_{4} 8,11 \%$ (b/v), kecepatan putar pengaduk $500 \mathrm{rpm}$ dan suhu $70^{\circ} \mathrm{C}$. Kemurnian LTJ yang didapat sebesar $97 \%$ dan recovery $95 \%$. Penelitian ini akan dilanjutkan dengan proses pemurnian untuk menghasilkan LTJ dengan kemurnian tinggi. Larutan yang dihasilkan dimurnikan lebih lanjut dengan ekstraksi pelarut menggunakan ekstraktan organik dalam minyak tanah. Ekstraksi pelarut biasanya digunakan untuk memisahkan LTJ individu

\section{UCAPAN TERIMA KASIH}

Penulis mengucapkan terimakasih kepada Pusat Sains dan Teknologi Akselerator (PSTA BATAN), yang telah menyediakan bahan dan fasilitas yang dibutuhkan untuk melakukan penelitian serta kepada para pegawainya yang telah membantu penulis dalam melakukan penelitian.

\section{DAFTAR PUSTAKA}

Behera, S.K., Meena, H., Chakraborty, S., dan Meikap, B.C. Application of response surface methodology (RSM) for optimization of leaching parameters for ash reduction from low-grade coal. Int. J. Min. Sci. Technol. 2018;28(4):621-629

Bellamy, L.J., dan Pace, R.J. Hydrogen bonding in carboxylic acids-I. Oxalic acids. Spectrochim Acta. 1963;19(2):435-42

Binnemans, K., Tom, P., Blanpain, B., Gerven, T. V., Yang. Y., dan Walton, A. Recycling of rare earths : a critical review. J. Clean Prod. 2013;51:1-22.

Galvin, J., dan Safarzadeh, M.S. Decomposition of monazite concentrate in potassium hydroxide solution. Journal of Environmental Chemical Engineering. 2018;6:1353-63.

Harjanto, S., Virdhian, S., dan Afrilinda, E. Characterization of Indonesia rare earth minerals and their potential processing techniques, Proceedings of the 52nd Conference of Metallurgists (COM) (Montreal), 2013.

Honary, S., Ebrahimi, P., dan Hadianamrei, R. Optimization of particle size and encapsulation efficiency of vancomycin nanoparticles by response surface methodology, Pharmaceutical Development and Technology. 2014;19(8):987-998.

Hoshino, M., Sanematsu, K., dan Watanabe, Y. REE Mineralogy and Resources. In: Handbook on the Physics and Chemistry of Rare Earths. 1 ed. Tsukuba: Elsevier B.V. 2016;129-291.

Jordens, A., Cheng, Y.P., dan Waters, K.E. A review of the beneficiation of rare earth element bearing minerals. Miner Eng. 2013;41:97-114

Krishnamurthy, N., dan Gupta, C.K. Extractive metallurgy of rare earths, second edition. Extractive Metallurgy of Rare Earths. 2015;1-809

Liu, F., Porvali, A., Wang, J., Wang, H., Peng, C., dan Wilson, B.P. Recovery and separation of rare earths and boron from spent $\mathrm{Nd}-\mathrm{Fe}-\mathrm{B}$ magnets. Miner Eng. 2020;145:106097

Myers, R.H., Montgomery, D.C., dan AndersonCook, C.M. Response surface methodology: process and product optimization using designed experiments. John Wiley \& Sons. 2016

Petrus, H.T.B.M, Wijaya, A., Iskandar, Y., Bratakusuma, D., Setiawan, H., Wiratni, dan Astuti, W. Pengambilan Lantanum dan Nikel dari Katalis Bekas Menggunakan Asam Sitrat: Peninjauan Performa secara Kuantitatif Menggunakan Response Surface Method. Metalurgi. 2018;33(2):91-100.

Prameswara, G., Trisnawati, I., Poernomo, H., Mulyono, P., Prasetya, A., dan Petrus, H.T.B.M. Kinetics of Yttrium Dissolution from Alkaline Fusion on Zircon Tailings. Mining, Metallurgy \& Exploration. 2020.

Silva, R.G., Morais, C.A., Teixeira, L.V., dan Oliveira, É.D. Selective Precipitation of High-Quality Rare Earth Oxalates or Carbonates from a Purified Sulfuric Liquor Containing Soluble Impurities. Mining, Metall Explor. 2019;36(5):967-77.

Virdhian, S., dan Afrilinda, E. Karakterisasi Mineral Tanah Jarang Ikutan Timah dan Potensi Pengembangan Industri Berbasis Unsur Tanah Jarang. Metal Indonesia. 2018;36(2):61-69.

Xie, F., An, T., Dreisinger, D., dan Doyle, F. A critical review on solvent extraction of rare earths from aqueous solutions. Miner Eng. 2014;56:10-28. 